\title{
PROFIL PEMASARAN ONLINE USAHA KERAJINAN TOPENG DAN KAYU BATIK DESA BOBUNG GUNUNGKIDUL
}

\author{
Dwi Maryono $^{1}$, Slamet Subiyantoro² ${ }^{2}$ Susilaningsih $^{3}$ \\ ${ }^{1}$ Program Studi Pendidikan Teknologi Informasi dan Komputer, Universitas Sebelas Maret Surakarta \\ \Email: dwimaryono@staff.uns.ac.id \\ ${ }_{2}^{2}$ Program Studi Pendidikan Seni Rupa, Universitas Sebelas Maret Surakarta \\ ${ }^{3}$ Program Studi Pendidikan Akuntansi, Universitas Sebelas Maret Surakarta
}

\begin{abstract}
$\overline{P e n e l i t i a n}$ ini bertujuan untuk mengetahui profil atau gambaran pemanfaatan teknologi IT dalam pemasaran atau pemasaran online produk kerajinan topeng dan kayu batik di desa Bobung, Putat, Kecamatan Pathuk Gungungkidul. Hasil penelitian menunjukkan bahwa pada dasarnya para pengrajin menyadari betul akan pentignya pemasaran secara online, sebagai alternatif media pemasaran yang ada selama ini yang lebih mengandalkan pada kegiatan pameran, brosur, dan informasi dari mulut ke mulut. Namun demikian di antara para pengrajin, baru $45 \%$ yang sudah mencoba menggunakan media online sebagai sarana pemasaran. Belum diterapkannya pemasaran online lebih pada kurangnya peralatan dan SDM untuk pengelolaan pemasaran secara online. Namun demikian melihat perkembangan teknologi informasi saat ini, terutama perangkat HP smartphone, masalah peralatan semestinya sudah tidak menjadi masalah karena dalam perangkat HP peralatan seperti koneksi internet, web, dan kamera dalam satu perangkat. Oleh karena itu penggunaan e-commerce mulai bergeser dengan m-commerce (mobile commerce), meskipun implementasinya m-commerce tidak bisa dipisahkan dengan e-commerce atau bisa disebut bahwa m-commerce merupakan salah satu bentuk dari e-Commerce.
\end{abstract}

Kata kunci-Pemasaran Online, Kerajinan Topeng, Kayu Batik, E-Commerce

This study aims to determine the profile or description of the use of IT technology in marketing or online marketing of mask and wood craft products in the village of Bobung, Putat, Pathuk Gungungkidul District. The results showed that basically the craftsmen were well aware of the importance of online marketing, as an alternative to the existing marketing media that had relied more on exhibitions, brochures, and word of mouth information. However, among the craftsmen, only $45 \%$ have tried to use online media as a marketing tool. Not yet implemented online marketing is more on the lack of equipment and HR for online marketing management. However, seeing the development of information technology at this time, especially HP smartphone devices, equipment problems should not be a problem because in HP devices such as internet connections, the web, and cameras in one device. Therefore the use of e-commerce began to shift with mcommerce (mobile commerce), although the implementation of m-commerce cannot be separated from ecommerce or it can be said that m-commerce is a form of e-commerce..

Keywords - Online Marketing, Mask Craft, Batik Wood, E-Commerce

(C) 2019 JBTI. All rights reserved

Article History : Received: 2019-10-14; Revised: 2019-10-22; Accepted: 2019-11-29 


\section{PENDAHULUAN}

Pemasaran merupakah salah satu bagian terpenting dalam unit usaha, yang tidak kalah penting dari unit produksi itu sendiri. Pemasaran menjadi nyawa bagi sebuah unit usaha untuk bisa mempertahankan kelangsungan hidupnya. Sebuah usaha bisnis meskipun dengan hasil produk yang biasa saja bisa meraih sukses jika diiringi dengan strategi pemasaran yang baik dan handal. Namun sebaliknya sebuah perusahaan dengan produk yang berkualitas tidak akan mempunyai omset penjualan yang bagus jika tidak diiringi dengan strategi pemasaran yang tepat.

Pemasaran dapat diartikan upaya untuk mempromosikan, menginformasikan dan menawarkan kepada konsumen mengenai sebuah produk usaha atau layanan jasa yang dikelola oleh sebuah perusahaan sebagai upaya untuk meningkatkan angka penjualan produk atau layanan jasa tersebut. Menurut Agustina Shinta (2011), pemasaran adalah suatu proses dan manajerial yang membuat individu atau kelompok mendapatkan apa yang mereka butuhkan dan inginkan dengan menciptakan, menawarkan dan mempertukarkan produk yang bernilai kepada pihak lain atau segala kegiatan yang menyangkut penyampaian produk atau jasa mulai dari produsen sampai konsumen. Peranan pemasaran saat ini tidak hanya menyampaikan produk atau jasa hingga tangan konsumen tetapi juga bagaimana produk atau jasa tersebut dapat memberikan kepuasan kepada pelanggan dengan menghasilkan laba. Sasaran dari pemasaran adalah menarik pelanggan baru dengan menjanjikan nilai superior, menetapkan harga menarik, mendistribusikan produk dengan mudah, mempromosikan secara efektif serta mempertahankan pelanggan yang sudah ada dengan tetap memegang prinsip kepuasan pelanggan.

Seiring dengan perkembangan teknologi, pemasaran saat ini sudah menggunakan berbagai media dan teknologi komunikasi dan informasi. Salah satunya adalah pemanfaatan teknologi internet. Dengan penggunaan teknologi seperti internet pemasaran akan menjangkau pasar yang lebih luas tidak hanya sekedar lintas daerah namun bisa lintas wilayah dalam negara hingga mancanegara. Tidak sekedar sebagai media promosi saja penggunaan teknologi informasi juga memudahkan usaha bisnis dan pelanggannya juga menyediakan cara melakukan transaksi secara elektronik sehingga lebih mudah, cepat, dan aman. Oleh karena itu muncul istilah e-Commerce atau perdagangan secara elektronik. Mau tidak mau setiap pelaku usaha terutama usaha kecil dan menengah harus tahu bagaimana pemanfaatan teknologi semacam ini karena persaingan usaha yang semakin ketat, siapa yang tidak mengikui perkembangan jaman akan tergerus dengan sendirinya.

Dalam hal ini termasuk usaha kerajinan topeng dan batik kayu di Desa Bobung juga. Seni kerajinan topeng merupakan salah satu warisan budaya yang turun temurun yang sampai saat ini masih dilestarikan oleh para pengrajin di Desa Bobung, Putat, Kecamatan Pathuk Gunung Kidul. Perajin selain memproduksi topeng klasik, juga mengembangakan kerajinan topeng batik sebagai variasi dari topeng klasik, dan juga membuat aneka kerajinan kayu batik untuk menopang jalannya usaha karena permintaan terhadap kerajinan topeng klasik yang terbatas.

Salah satu faktor yang mendukung kelangsungan usaha kerajinan ini adalah pemasaran. Berdasarkan observasi awal, pemasaran sebagain besar dilakukan masih secara tradisional seperti melalui brosur dan leaflet, mengikuti pameran, menitipkan produk di beberapa show room dan sebagainya. Meskipun teknologi sudah berkembang dengan adanya internet, media sosial, toko online (market place), blog dan sebagainya, namun demikian pada saat ini hampir sebagian besar pengrajin belum memanfaatkan teknologi TI secara maksimal. Padahal banyak penelitian menunjukkan bahwa pemanfaatan TI untuk pemasaran terbukti bisa meningkatkan omset dari usaha kecil dan menengah terutama usaha kerajinan. 
Sholihin dan Mujilahwati (2016) melakukan penelitian mengenai dampak pemanfaatan eCommerce pada UMKM Kerajinan Bross di Lamongan. Hasilnya adalah dengan e-Commerce, omset UMKM bisa meningkat sebesar 25\% dibandingkan sebelumnya. Hasil yang serupa juga diperoleh Helmalia dan Afrinawati (2018), di mana pemanfaatan e-Commerce mempunyai efek yang signifikan dalam meningkatkan pendapatan 108 unit UMKM binaan RKB BNI kota Padang.

Andriyanto (2018) menyatakan, berdasarkan penelitian pemanfaatan e-Commerce pada unit UMKM, ada beberapa dampak yang dirasakan oleh pelaku bisnis UMKM, di antaranya adalah : 1) Pemasaran yang semakin meluas, 2) Menghemat Biaya, 3) Tambah relasi, 4) kemudahan dalam bertransaksi, 5) menambah penghasilan.

Seiring dengan dampak positif yang diperoleh dengan penerapan pemasaran online ataupun ecommerce, maka sudah saatnya para pengrajin mulai memanfaatakan teknologi informasi untuk mendukung pemasaran produk kerajinannya. Namun demikian untuk melakukannya perlu strategi yang tepat dalam penerapannya sesuai dengan sumber daya yang yang ada dan kendala yang dihadapi oleh para pengrajin dalam menerapkan pemasaran online.

Oleh karena itu dalam penelitian ini digali informasi mengenai profil pemasaran dari unit kerajinan di Desa Bobung ini terutama terkait dengan pengggunaan teknologi informasi dan kendala yang dihadapi agar pemilihan dan penggunaan teknologi yang dipilih lebih tepat.

\section{KAJIAN TEORI}

Definisi kata profil Kamus Besar Bahasa Indonesi (KBBI) salah satunya adalah grafik atau ikhtisar yang memberikan fakta tentang hal-hal khusus (https://kbbi.web.id/ ). Sedangkan pemasaran online atau biasa disebut internet marketing, electronic marketing, atau online marketing yaitu segala upaya yang dilakukan untuk melakukan pemasaran suatu produk atau jasa melalui atau menggunakan media elektronik atau Internet. Menurut Kaur, dkk (2015), E-commerce menyediakan kemampuan untuk membeli dan menjual produk, penyediaan informasi dan layanan di Internet dan lingkungan online lainnya. Pemasaran online adalah elemen penggerak strategi dan kegiatan pemasaran ke lingkungan yang terkomputerisasi seperti Internet. Internet marketing sebagai "proses membangun dan memelihara hubungan pelanggan melalui aktivitas online untuk memfasilitasi pertukaran ide, produk dan layanan yang memuaskan tujuan kedua belah pihak.

Oleh karena itu yang dimaksud profil pemasaran online dalam penelitian ini bisa diartikan ringkasan data (ikhtisar), grafik, diagram, atau tulisan yang menggambarkan fakta atau keadaan bagaimana kegiatan pemasaran online yang dilakukan oleh para pengrajin di Desa Bobung, Putat, pathuk Guungkidul.

\section{METODE PENELITIAN}

Penelitian ini merupakan penelitian deskriptif, yaitu untuk mengetahui gambaran mengenai profil pemasaran online dari pengrajin topeng dan kayu batik di Desa Bobung, Putat, Pathik Gunung Kidul. Data profil yang dikumpulkan berupa data kuantitatif dalam bentuk angka atau kualitatif dalam bentuk kata verbal. Teknik pengambilan data adalah dengan menggunakan angket terhadap 20 responden dan dikuatkan dengan wawancara kepada beberapa responden di antaranya. Pengambilan data dilakukan pada bulan April 2018. 


\section{HASIL DAN PEMBAHASAN}

\section{Profil Pemasaran Online Pengrajin Di Desa Bobung}

Berikut ini hasil pengumpulan data mengenai profil pemasaran online para pengrajin topeng dan kayu batik yang diperoleh dengan angket dan wawancara.

\section{a. Pangsa Pasar}

Hasil pengumpulan data mengenai pangsa pasar usaha kerajinan topeng dan kayu batik di Desa Bobung adalah seperti pada Gambar 1.

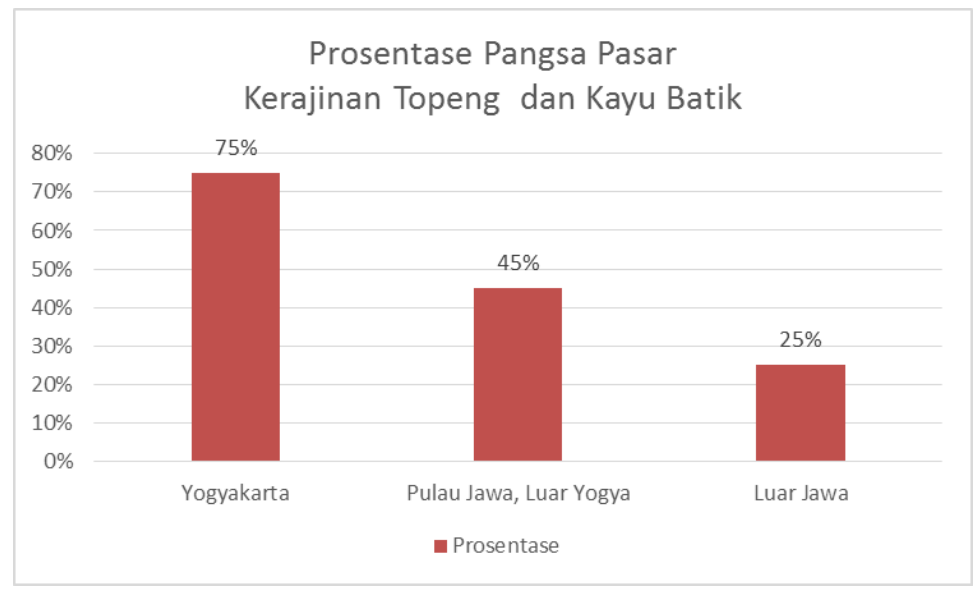

Gambar 1. Pangsa Pasar Usaha Kerajinan Desa Bobung

Berdasarkan Gambar 8.1, dapat dilihat bahwa $75 \%$ pengrajin mempunyai pangsar di daerah Yogyakarta, $45 \%$ pengrajin mempunyai pangsa pasar di luar Yogyakarta namun masih di Pulau Jawa, dan $25 \%$ di antaranya mempunyai pangsa pasar di Luar Jawa. Bahkan dari hasil wawancara, beberapa UKM bahkan sudah menembus pasar luar negeri seprti UKM Karya Manunggal dan UKM Bina Usaha ke beberapa negara seperti Amerika, Kanada, dan Singapura.

Dari data di atas menunjukkan bahwa pangsa pasar hasil kerajinan cukup bervariasi mulai dari daerah lokal, nasional hingga internasional. Ini artinya keberterimaan pasar terhadap produk ini sangat baik. Produk yang dihasilkan memiliki nilai seni dan artistik yang sangat tinggi sehingga diminimati oleh pasar baik domestic sampai mancanegara. Oleh karena itu pemanfaatan IT seperti internet dan website sebagai sarana pemasaran online akan lebih mengenalkan produk kerajinan topeng kayu ini lebih luas mengingat internet menghubungkan jutaan komputer dan milyaran pengguna di seluruh dunia.

\section{b. Media Promosi Produk Kerajinan}

Data mengenai media promosi dari UKM kerajinan dapat dilihat pada Gambar 2. Berdasarkan Gambar 2 dapat dilihat bahwa media promosi yang paling sering digunakan adalah Pameran, di mana $60 \%$ dari UKM menggunakan pameran sebagai media promosi. Selain melalui pameran, media promosi yang sering dipakai adalah promosi dari mulut- ke mulut sebesar $50 \%$, di mana kerajian topeng dan kayu batik yang ada dikenal dari testimoni pada pembeli yang ddiinformasikan kepada calon pembeli yang lain. Media promosi berikutnya menggunakan media online sebesar $26 \%$ dari pengarajin telah menggunakan media pemasaran online. 


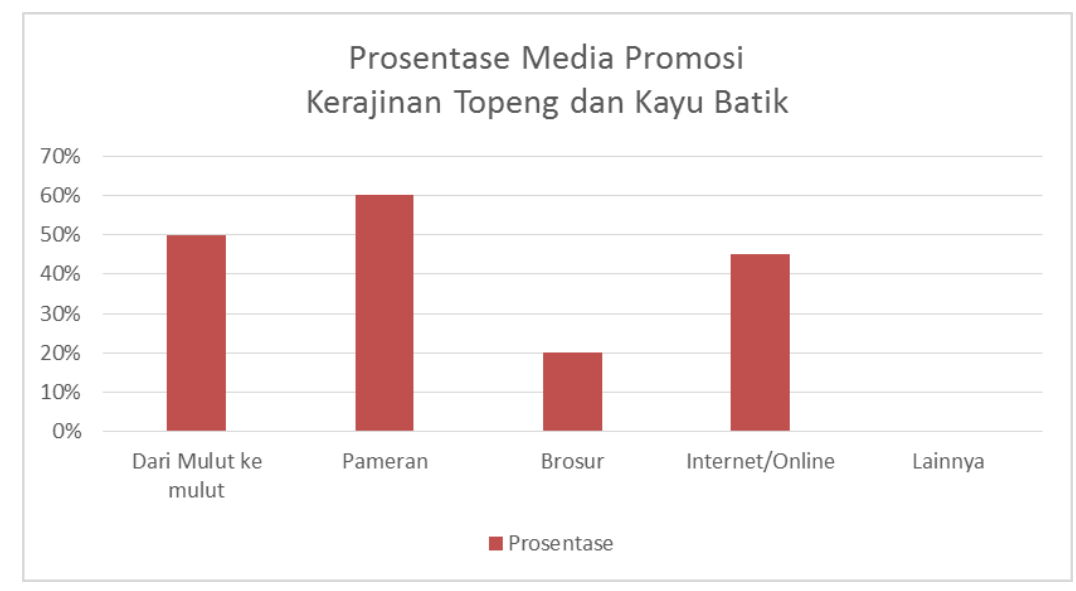

Gambar 2. Media Promosi Kerajinan Topeng dan Kayu Batik

Berdasarkan hasil wawancara, responden menyatakan bahwa pameran merupakan media yang paling efektif untuk memasarkan produk. Salah satu pameran yang paling sering diikuti ada event INACRAFT. Namun seiring dengan biaya yang cukup besar untuk mengikuti kegiatan tersebut baik biaya pendaftaran dan transportasi, banyak UKM yang tidak lagi bisa mengikuti event tersebut. Oleh karena itu perlu dicari alternatif lain memaksimalkan promosi, dalam hal ini pemanfaatan teknologi informasi, khususnya internet.

Berdasarkan Gambar 2, dapat dilihat bahwa hanya 45\% saja yang sudah menggunakan pemasaran online sisanya $55 \%$ belum bisa menggunakan pemasaran online. Ada beberapa alasan mengapa tidak digunakan media online adalah sebagai berikut.

1) Belum ada jaringan wifi

2) Baru berdiri

3) Belum punya karyawan, baik SDM untk mengelola maupun SDM untuk memenuhi permintaan yang terlalu banyak

4) Belum ada fasilitas

Berdasarkan wawancara lebih lanjut kurangnya SDM yang memiliki kemampuan TI yang cukup menjadi hambatan. Hal ini disebabkan pelaku usaha kerajinan rata-rata usainya sudah tidak muda lagi sehingga agak kesulitan untuk megoperasikan berbagai peralatan IT seperti komputer atau handphone terutama untuk penggunaan media sosial ataupun internet. Peralatan IT seperi handphone hanya digunakan sebagai sarana berkomunikasi seperti telepon, SMS atau WhatsApp Mesenger.

\section{c. Teknologi Pemasaran Online}

Ada beberapa teknologi yang digunakan UKM dalam memasarkan produknya secara online, di antaranya Website/Blog sebesar 26\%, Toko Online sebesar 26\%, media sosial sebesar $47 \%$ dan lainnya sebesar $11 \%$. Di antara usaha kerajinan yang memanfaatakan pemasaraan online, ada beberapa teknologi yang digunakan. Berdasarkan Gambar 3 dapat dilihat bahwa teknologi yang paling banyak digunakan adalah media sosial seperti facebook dan instagram, berikutnya diikuti dengan web/blog, dan toko online. 


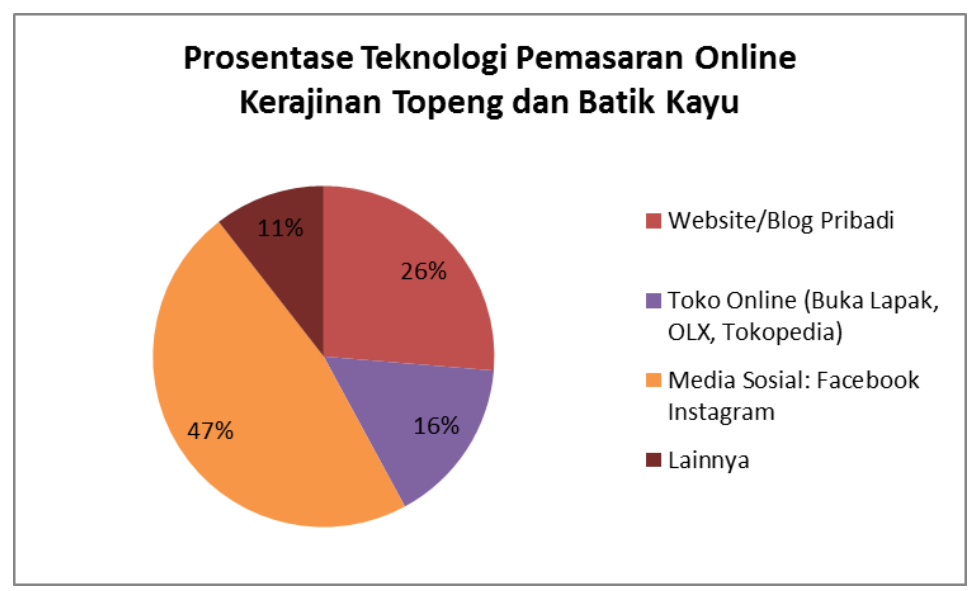

Gambar 3. Teknologi yang digunakan untuk pemasaran online

Hal ini tidak mengherankan karena saat ini hampir semua orang sudah memiliki akun media sosial. Namun demikian pengunaan Facebook dan Instagram memiliki keterbatasan, di mana penyebaran informasi hanya terbatas pada pengguna yang terhubung dengan penggunanya sehingga cakupan kurang begitu luas. Selain itu, dengan media sosial fitur-fitur pendukung pemasaran online terbatas. Penggunaan website/blog maupun toko online sebenarnya mempunyai cakupan dan jangkauan yang lebih luas dan lebih fleksibel dalam menerapkan fitur pemasaran online.

\section{d. Pengalaman Transaksi Online}

Dari Gambar 4, di antara usaha kerajinan yang melakukan pemasaran online $44 \%$ di antaranya sudah menerapkan transaksi online. Salah satu alasan mengapa tidak menggunakan transaksi online adalah masih kurangnya tingkat kepercayaan baik dari pihak pengrajin maupun pembeli dalam melakukan pemesanan dan pembayaran secara online.

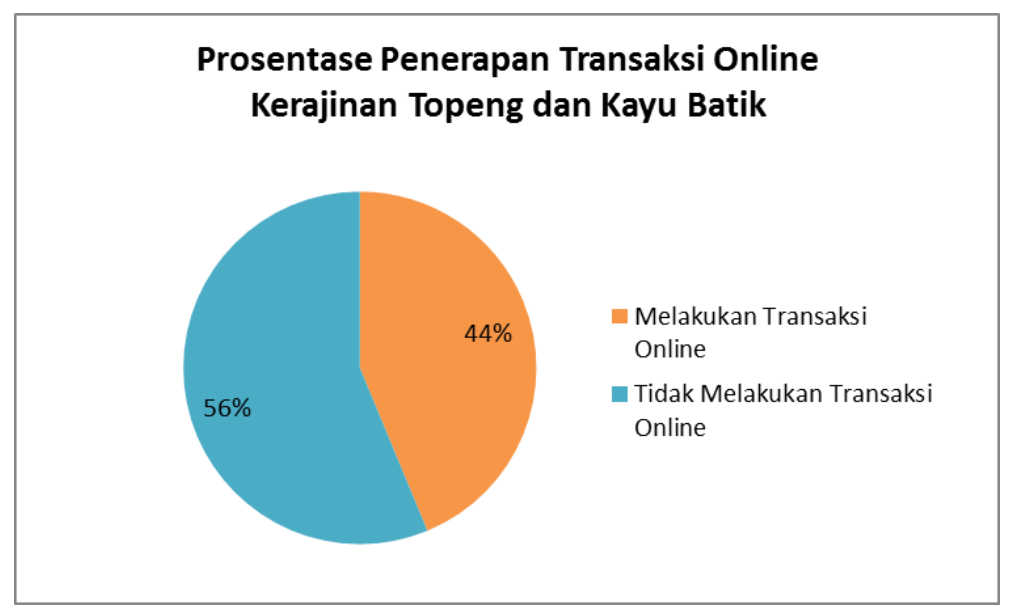

Gambar 4. Prosentase kegiatan usaha kerajianan yang melakukan transaksi online

Berdasarkan wawancara dengan beberapa pengrajin kerajinan topeng kayu, ada beberapa kendala atau permasalahan yang dihadapi dalam penerapan e-Commerce yang menjadi 
pertimbangan mengapa beberapa pengrajin kurang yakin untuk melakukan transaksi online. Di antaranya adalah kurangnya kepercayaan para pengrajin pada keamanan transaksi, karena pada beberapa kasus ada beberapa calon pembeli yang memesan produk namun seiring dengan selesainya produk, calon pembeli membatalkan pesanan atau bahkan tidak bisa dihubungi.

Hal ini dikarenakan e-Commerce yang diterapkan tidak menerapkan standar baku eCommerce yang pada intinya melindungi kedua belah pihak. Salah satu proses bisnis yang standar dalam e-Commerce sebagaimana pada market place seperti Buka Lapak atau Tokopedia, di mana market place menjamin keamanan transaksi kedua belah pihak. Ketika memesan barang calon pembeli harus membayarkan uang terlebih dahulu melalui rekening pihak ketiga dalam hal ini market place. Jika uang telah dibayarkan maka penjual akan mengirimkan pesanan. Jika pesanan sudah dterima oleh pembeli maka transaki selesai, kemudian market place akan mentransfer uang dari pembeli kepada penjual. Jika pesanan tidak sesuai dan ditolak pembeli maka pembeli akan mendapatkan uangnya kembali. Proses ini melindungi baik penjual dan pembeli sehingga semua pihak tidak ada yang dirugikan. Hal inilah yang kurang dipahami oleh sebagaian pengrajin bahwa kesamanan dalam e-Commerce terjamin selama menggunakan aturan-aturan yang baku seperti pada market place.

Kendala lain adalah adanya ketidaksesuaian produk yang menjadi alasan kosnumen membatalkan transaksi. Berdasarkan wawancara dengan pengrajin ada kasus di mana konsumen menyatakan produk yang dikirim tidak sesuai dengan contoh gambar yang dipasang. Hal ini disebabkan karena produk yang dijual merupakan hasil kerajinan tangan sehingga bisa saja setiap kali pembuatan ada sedikit perbedaan (unik) baik dari sisi model, pewarnaan dan sebagainya. Oleh karena itu solusinya adalah senantiasa memperbarui foto produk dengan produk yang akan dijual, tidak menggunakan foto dari produk terdahulu. Selain itu foto harus senatural mungkin, tidak melalui proses editing atau menggunakan efek khusus sehingga nampak lebih baik dari aslinya.

\section{e. Pengembangan Website/Blog Pemasaran Online}

Untuk pemanfaatan web dan blog untuk pemasaran online, 67\% UKM sudah bisa mengembangkan web/blog secara mandiri, dan 33\% dibuatkan oleh pihak lain.

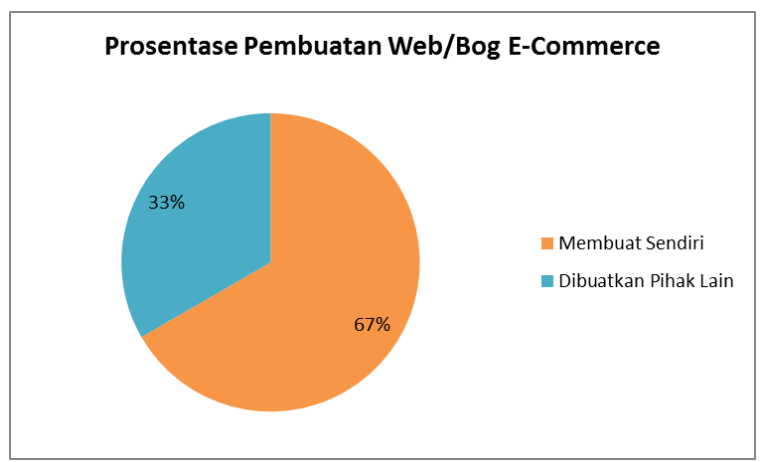

Gambar 5 Prosentase Usaha kerajianan yang membuat web/blog sendiri untuk pemasaran online

\section{f. Kendala Pengembangan Pemasaran Online}

Kendala yang dihadapi oleh para pengrajin dalam mengembangkan pemasaran online adalah sebagaimana pda Gambar 6. Kendala yang paling besar adalah masalah peralatan pengembangan media online yang terbatas seperti komputer, laptop dan jaringan internet. Selain itu kurangnya 
pendampingan daam pengoperasian media online juga menjadi kendala, yaitu sebesar $29 \%$. Kendala berikutnya adalah SDM yang kurang memadai dalam pengoperasian media pemasaran online.

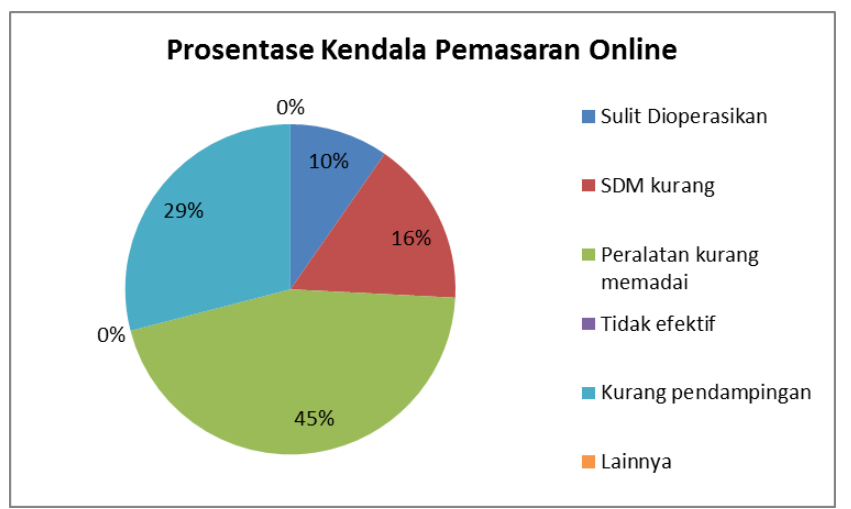

Gambar 6. Prosentase kendala pemasaran online

\section{g. Peralatan pendukung Pemasaran Online}

Di antara peralatan yang dimiliki para pengrajin untuk pendukung pemasaran secara online dapat dilihat pada Gambar 7. Secara garis besar peralatan yang hampir dimiliki semua pengrajin adalah smartphone. Sebanyak $95 \%$ responden memiliki HP Smart Phone yang dapat digunakan untuk pemasaran online. Untuk peralatan laian hanya $25 \%$ saja yanh memiliki laptop, $5 \%$ memiliki komputer PC dan hanya $5 \%$ memiliki kamera digital. Haln ini menjadi sebuah pertimbangan bagaimna pengembangan media pemasaran onlue bagi para pengrajin di Desa Bobung. Tentu media pemasaran online yang dapat dengan mudah dijalankan pada HP Smatphone menjadi pertimbnagan yang paling utama. Dan ini tentu sangat dimungkinkan mengingat HP Smartphone sudah dilengkapi dengan banyak fitur, baik secara aplikasi, kamera, hingga jaringan internet.

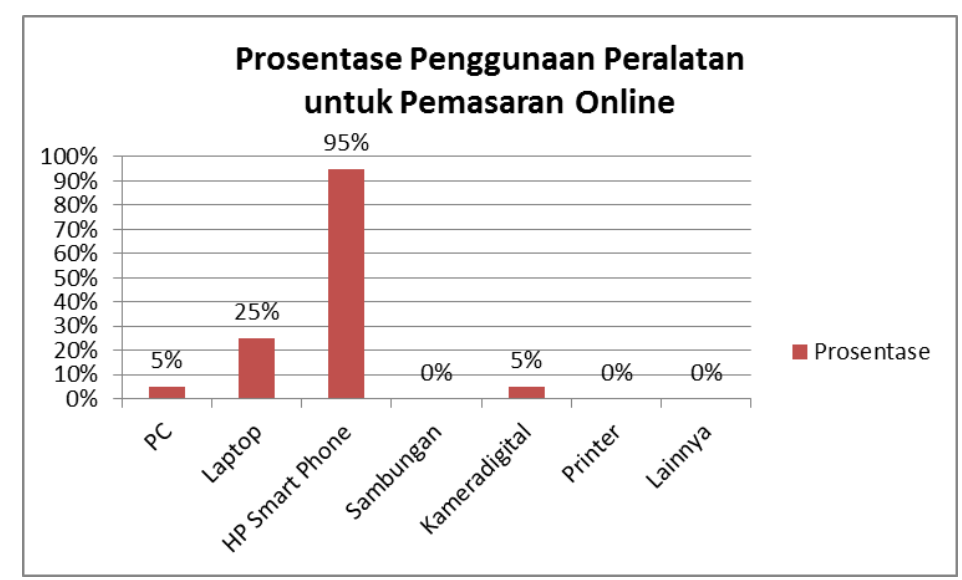

Gambar 7. Prosentase penggunaan peralatan untuk pemasaran online 


\section{h. Persepsi pentingnya pemasaran online}

Berdasarkan hasil angket, semua pengrajin menyadari akan pentingnya pemanfaatan pemasaran online sebagai untuk mempromosikan produk, di mana $100 \%$ di antara responden memberikan jawan "Ya" untuk perlunya pemasaran secara online. Beberapa alasan disampaikan para pengrajin sebagai berikut.

1) Pemasaran online membantu promosi

2) Karena dengan pemasaran online kita bisa memasarkan produk kita sampai luar negeri tidak hanya di Pulau Jawa

3) Kesulitan jaringan internet, tidak bisa maksimal

4) Pemasaran online dapat menjangkau seluruh dunia namun pengoperasiannya yang kurang (seperti bukalapak)

5) Kecepatan dalam transaksi muapun pemasaran serta promosi

6) Untuk mempermudah pemasaran

7) Mencakup jaringan luas

8) Karena internet media yang bisa dibuka setiap saat 24 jam sehari, maka dari itu kita dapat menyampaikan info produk ukm dan bisa dikases dengan mudah oleh semua orang tana ada gangguan

9) Karena saat ini semua kegiatan bisa dikases secara online

10) Karena dengan perkembangan teknologi agar dengan mudah konsumen mengetahui tentang produk yang dibuat

11) sarana promosi hasil produk dengan adanya pemasaran online, jangkauan menjadi luas dan tidak terbatas. Konsumen dapat menemukan produk kita di manapun mereka berada selama terdapat koneksi internet

Dari beberapa pernyataan di atas dapat dilihat bahwa para pengrajin menyadari betul pentingnya pemasaran online untuk mempromosikan produk kerajinan.

\section{i. Kriteria Pengambangan Pemasaran Online}

Untuk itu di akhir angket, digali mengenai kriteria pengembangan pemasaran online. Lebih jelasnya dapat dilihat pada Gambar 8.

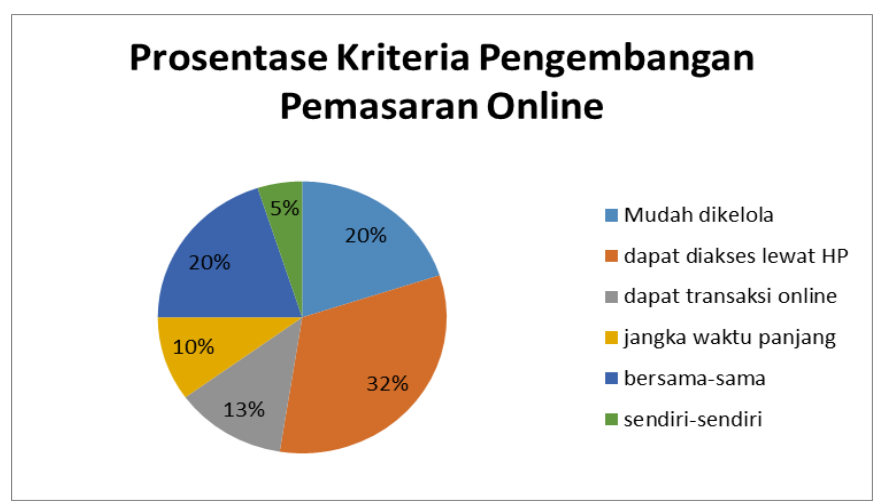

Gambar 8 Kriteria Pengembangan Pemasaraan Online yang diharapkan oleh Usaha Kerajinan 
Pertimbangan yang paling diperhatikan adalah para pengrajin menghendaki media pemasaran online dapat diakses dengan mudah menggunakan Handphone (smartphone). Hal ini mengingat bahwa peralatan yang pasti dimiliki adalah Handphone, sehingga tidak perlu memerlukan peralatan lain seperti komputer, laptop, modem dan peralatan lain. Kriteria berikutnya adalah media yang dikembangkan sebisa mungkin mudah dikelola dan dioperasikan, karena kendala yang pernah dihadapai adalah kurangnya pendampingan. Oleh karena itu sebisa mungkin media pemasaran yang dikembangkan bersifat user friendly, tidak memerlukan fitur-fitur yang rumit sehingga mudah dioperasikan dan dikelola. Hal ini juga terkait dengan kuragnya SDM untuk pengelolaan media pemasaran online. Kriteria sebagai pertimbangan berikutnya adalah media yang bisa digunakan bersama-sama.

Berdasarkan hasil pengumpulan data di atas diperoleh beberapa fakta bagaimna penerapan pemasaran online dan e-commerce pada usaha kerajinan topeng kayu di desa Bobung. Di antara 20 responden, baru $45 \%$ di antaranya yang menggunakan TI untuk pemasaran online. Kendala yang dihadapi salah satunya adalah terkait dengan kurangnya SDM, perangkat teknologi informasi, dan kekurangpercayaan terhadap proses transaksi secara online. Di antara pengrajin yang sudah memanfaatkan teknologi informasi tersebut menggunakan beberapa media untuk melakukan pemasaran online atau e-Commerce.

Teknologi yang pernah dimanfaatkan diamanfaatkan adalah website/blog, Toko Online, Media sosial, dan lainnya. Di antara media tersebut yang paling banyak paling banyak digunakan adalah media sosial sebesar 47\%. Kelebihan dan kekurangan penggunaan media sosial untuk pemasaran ini, menurut Nadaraja dan Yazdanifard (2013) adalah sebagai berikut. Kelebiah penggunaan media sosial meliputi: 1) perusahaan bisa memberikan informasi yang tak terbatas kepada konsumen tanpa intervensi pihak lain; 2) perusahaan dapat menciptakan interaksi langsung dengan konsumen sehingga memungkinkan konsumen bisa melakukan kustomisasi produk sesuai dengan kebutuhannya. Sedangkan kekurangannya adalah : 1) Membutuhkan waktu yang intensif; 2) adanya isu pelanggaran hak cipta atau merk dagang; 3 ) adanya masalah kepercayaan (trust), privasi, dan keamanan; 4) adanya umpan balik negatif (negative feedback), yang terkadang tidak dari konsumen sebenarnya namun bisa dari persaingan yang tidak sehat. Selain itu pemasaran menggunakan media sosial mempunyai cakupan yang terbatas, yaitu pada kenalan atau follower dari akun yang bersangkutan saja.

Di antara pengrajin yang menerapkan pemasaran online, masih sedikit yang menggunakan toko online (market place), hanya sebesar 16\% saja. Padahal terkait dengan keamanan kemudahan kepraktisan, toko online atau market place ini lebih luas jangkauannya dan dilengkapi dengan berbagai fitur termasuk untuk transaksi online yang menjamin kemanannya baik dari sisi penjual maupun pembeli. Berikut ini kelebihan dan kekurangan penggunaan market place sebagai media pemasaran online, dikutip dari https://www.jurnal.id/id/blog/2018-kelebihan-dan-kekuranganberbisnis-online-di-marketplace-yang-perlu-diketahui/. Kelebihannya di antaranya: 1) tempat berkumpulnya para pembeli; 2) banyak relasi pedagang; 3) adanya promosi gratis dari market place, terkadang bisa melalui media sosial; 4) tersedianya rekening bersama untuk menjamin keamanan transaksi; 5) sewa toko murah (gratis); 6) jangkauan lebih luas; 7) lebih meyakinkan untuk pembeli. Sedangkan kekurangannya adalah: 1) persaingan antar pedagang tinggi; 2) keberlangsungan marketplace tidak terjamin; 3) Adanya fee untuk marketplace; 4) pedagang tidak mempunyai kontrol terhadap marketplace, harus tunduk pada aturan yang dibuat; 5) adanya fitur premium; 6) peraturan yang ketat; 7) brand awaraness lemah; 8) pembayaran lebih lama. 
Dalam menerapkan pemasaran secara online, kendala yang paling besar menurut para pengrajin adalah peralatan yang kurang memadai diikuti dengan kurangnya pendampingan, SDM, sulitnya pengoperasian dari media yang digunakan. Hal ini senada dengan yang disampaikan oleh Deputi Produksi dan Pemasaran Kementerian Koperasi dan UKM, I Wayan Dipta (2016), mengatakan dalam e-commerce, pelaku UKM masih terkendala bahasa dan teknologi, infrastruktur jaringan dan masalah keamanan (Money.kompas.com, 2016).

Di antara peralatan TI yang paling banyak dimiliki oleh pengrajin adalah mobile phone (handphone). Hal ini sebenarnya solusi dari permasalahan kurangnya peralatan TI dalam mengembangkan bisnis secara online. Karena dalam sebuah peralatan ini mempunyai banyak fungsi, tidak hanya sekedar untuk telepone atau berkirim pesan, namun peralatan ini sudah dilengkapi dengan berbagai fitur canggih seperti kamera, internet, berbagai macam aplikasi, navigasi, dan sebagainya. Oleh karena itu era e-commerce saat ini mulai bergeser pada mcommerce (mobile-commerce). Menurut Sandhu (2012), berikut ini alasan mengapa m-commece akan mengubah cara bisnis, yaitu:

1. Handphone sebagai alat komunikasi, tidak sekedar komunikasi suara, namun juga pengiriman pesan, email, juga bisa digunakan untuk pertukaran data dalam jumlah besar, gambar dan video

2. Handphone sebagai Connective device, yang menghubungkan orang dengan berbagai sumber data kapanpun dan di manapun

3. Handphone sebagai alat transaksi, di amana proses pembayaran dapat dilakukan secara praktis baik secara transfer melalui SMS, m-banking, atau e-banking, atau juga menggunakan e-wallet

4. Handphone merupakan intelligent device, di mana handphone dilengkapi dengan berbagai aplikasi yang "cerdas". Aplikasi-aplikasi tersebut disebut cerdas karena mampu mengumpulkan dan mengolah data sehingga mampu memberikan informasi yang akurat, melakukan prediksi hingga bisa digunakan baik secara otomatis atau tidak dalam pengambilan keputusan. Salah satu contohnya adalah adanya sistem rekomendasi bagi pelanggan dalam berbelanja.

Hampir semua jenis e-commerce saat ini dapat diakses melalui handphone. Oleh karena itu solusi kurangnya peralatan TI bagi para pengrajin untuk mengembangkan bisnis online dapat diatasi dengan memaksimalkan penggunaan peralatan ini. Hal ini diperkuat oleh Henri dan Utomo (2016) yang mengembangkan aplikasi mobile commerce sebagai media pendukung promosi dan penjualan produk UMKM. Hasil penelitian Henri dan Utomo (2016) menunjukkan bahwa adanya aplikasi mobile commerce ini dapat digunakan oleh UMKM untuk memperluas jangkauan pemasaran, sehingga dapat meningkatkan jumlah penjualan. Selain itu aplikasi mobile commerce ini membantu memudahkan pelanggan mendapatkan informasi tentang UMKM dan produk yang dijualnya dan dapat melakukan proses pemesanan dengan hanya menggunakan perangkat genggam yang mereka dimiliki tanpa harus datang ke outlet. Oleh karena itu optimaliasi penggunaan perangkat handphone dapat dilakukan sebagai media pemasaran online maupun ecommerce sebagai salah satu strategi meningkatkan pemasaran kerajinan topeng klasik dan batik tulis pengrajin di Desa Bobung.

\section{KESIMPULAN}

Dari penggalian data di atas dapat disimpulkan bahwa pada dasarnya para pengrajin menyadari betul akan pentignya pemasaran secara online, sebagai alternatif media pemasaran yang 
ada selama ini yang lebih mengandalkan pada kegiatan pameran, brosur, dan informasi dari mulut ke mulut. Namun demikian di antara para pengrajin, baru $45 \%$ yang sudah mencoba menggunakan media online sebagai sarana pemasaran. Belum diterapkannya pemasaran online lebih pada kurangnya peralatan dan SDM untuk pengelolaan pemasaran secara online. Namun demikian melihat perkembangan teknologi informasi saat ini, terutama perangkat HP smartphone, masalah peralatan semestinya sudah tidak menjadi masalah karena dalam perangkat HP peralatan seperti koneksi internet, web, dan kamera dalam satu perangkat. Oleh karena itu penggunaan e-commerce mulai bergeser dengan m-commerce (mobile commerce), meskipun implementasinya m-commerce tidak bisa dipisahkan dengan e-commerce. Pemanfaatan m-commerce ini bisa memanfaatan berbagai macam bentuk pemasaran online baik media sosial, market-place, blog ataupun gabungan dari ketiganya. Tentu saja pemanfaatan berbagai macam media online ini harus diiringi dengan pemahaman dan penguasaan teknologi e-commerce yang baku yang mampu melindungi keamanan transaksi baik konsumen ataupun produsen dalam hal ini adalah pihak pengrajin.

\section{DAFTAR PUSTAKA}

Agustina Shinta, 2011, Manajmen Pemasaran, Malang: Universitas Brawijaya Press.

Andriyanto, I., 2018, Penguatan Daya Saing Usaha Mikro Kecil Menengah Melalui E-Commerce, Jurnal Bisnis dan Manajemen Islam, Vol. 6 No. 2, Des 2018

https://money.kompas.com/read/2016/05/26/164038126/kemenkop.dorong.umkm.tingkatkan.bisnis. melalui.e-commerce, diakses 22 September 2019

https://www.jurnal.id/id/blog/2018-kelebihan-dan-kekurangan-berbisnis-online-di-marketplaceyang-perlu-diketahui/, diakses 22 September 2019

Helamlia dan Afrinawati, 2018, Pengaruh E-Commerce terhadap Peningkatan Pendapatan Usaha Mikro Kecil dan Menengah di Kota Padang, JEBI (Jurnal Ekonomi dan Bisnis Islam), Volume 3, Nomor 2, Juli - Desember 2018

Henri, C. L. dan Utomo, V. G., 2016, Aplikasi Mobile Commerce Berbasis Open Source untuk Mendukung Promosi dan Penjualan Produk UMKM, Jurnal Teknologi Informasi dan Komunikasi, Volume 7 Nomor 2 September 2016

Kaur, P dkk, 2015, E-Marketing -A Global Perspective, Int. Journal of Enginering Research and Application Vol 5 Issue 2 February 2015 pp 116-124

Nadaraja, Rubathee dan Yazdanifard, Assc. Prof. Dr. Rashad, 2013, Social Media Marketing: Advantages And Disadvantages, https://www.researchgate.net/publication/256296291_Social_Media_Marketing_Social_M edia_Marketing_Advantages_And_Disadvantages, diakses 22 September 2019

Palwinder Sandhu, 2012, Mobile Commerce: Beyond E-Commerce, IJCST Vol. 3, Iss ue 1, Jan March 2012.

Sholihin, M dan Mujilahwati S, 2016, Dampak Pemanfaatan E-Commerce Terhadap Peningkatan Penjualan Di Umkm (Studi Kasus Ninda Bros Lamongan), Jurnal TeknikA, Vol. 8, No 1, Maret 2016 